\title{
The diet of the Mediterranean Shag Phalacrocorax aristotelis desmarestii ROOSTING ALONG THE SLOVENIAN COAST
}

\section{Prehrana sredozemskega vranjeka Phalacrocorax aristotelis desmarestii na počivališčih vzdolž slovenske obale}

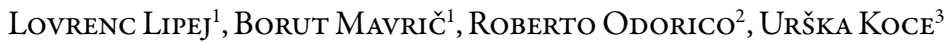 \\ Marine Biology Station, National Institute of Biology, Fornače 41, SI-6330 Piran, Slovenia \\ Shoreline, Società Cooperativa, Padriciano 99, IT-34149 Trieste-Trst, Italy \\ 3 DOPPS - BirdLife Slovenia, Tržaška cesta 2, SI-1000 Ljubljana, Slovenia
}

\begin{abstract}
Five hundred pellets of the Mediterranean Shag Phalacrocorax aristotelis desmarestii were collected at three roost-sites along the Slovenian coast and analysed. The diet was characterized mostly by the dominance of bottom dwelling fish species of the appropriate size. The Black Goby Gobius niger was the most dominant prey and represented the Shag's main prey in the studied area $(I R I \%=64.0)$. The results of the study confirm that the Mediterranean Shag preys mainly on fish species which are without commercial value for local fisheries.
\end{abstract}

Key words: piscivorous birds, roosts, otoliths, northern Adriatic

Ključne besede: ribojede ptice, počivališča, otoliti, severni Jadran

\section{Introduction}

The Mediterranean Shag Phalacrocorax aristotelis desmarestii is one of the three species of the family Phalacrocoracidae occurring in Slovenia. It inhabits the Mediterranean and the Black Seas. In the Gulf of Trieste, it has been a regular inhabitant since 1980 (SPONZA et al. 2010), where it can be sighted mainly during summer and autumn. The Mediterranean Shag population in Slovenian part of the Adriatic Sea is estimated at its seasonal peak at approximately 1,500 individuals, which corresponds to $5 \%$ of the subspecies' overall population. They gather at three communal roost-sites along the Slovenian coast (BORDJAN et al. 2013). Mediterranean Shag is considered to be a fishpreying top-predator which has a certain impact on the coastal fish assemblage (sensu Cosolo et al. 20 I I). For maintaining its population in the Slovenian part of the Adriatic Sea, it is important to understand basic biology of this population, especially its diet and prey availability dependence.

The aim of this paper was to gain knowledge about the Mediterranean Shag's diet in a shallow coastal area with a special focus on the qualitative and quantitative information on the impact of its predation on fish populations. This study is a first step in determining prey consumption by the Mediterranean Shag in
Slovenian waters, which is necessary to obtain information to assess the possible impact on local fisheries. This work was done within the framework of the project SIMARINE-NATURA (LIFE10NAT/ SI/141) Preparatory inventory and activities for the designation of marine IBAs and SPAs for Phalacrocorax aristotelis desmarestii in Slovenia.

\section{Material and methods}

The studied area is located in the Gulf of Trieste, which is the northernmost part of the Adriatic Sea (Figure 1). The southern part of the Gulf of Trieste constitutes the Slovenian part of the Adriatic Sea, a shallow area with a depth rarely exceeding $25 \mathrm{~m}$. The coastal area is characterised by rocky environment or sedimentary bottom such as sandy and muddy areas, which may be bare or densely populated by the marine phanerogam Cymodocea nodosa (LIPEJ et al. 2006).

The diet of the Mediterranean Shag was studied by analyzing the content of pellets. Although this method has some limitations (CASAUX 2003), such as the digestion of small otoliths or the underestimation of the real prey size among others, it is still one of the most used standardized techniques for assessing the diet of many raptorial birds, including herons, cormorants and shags. Pellets were collected at three 


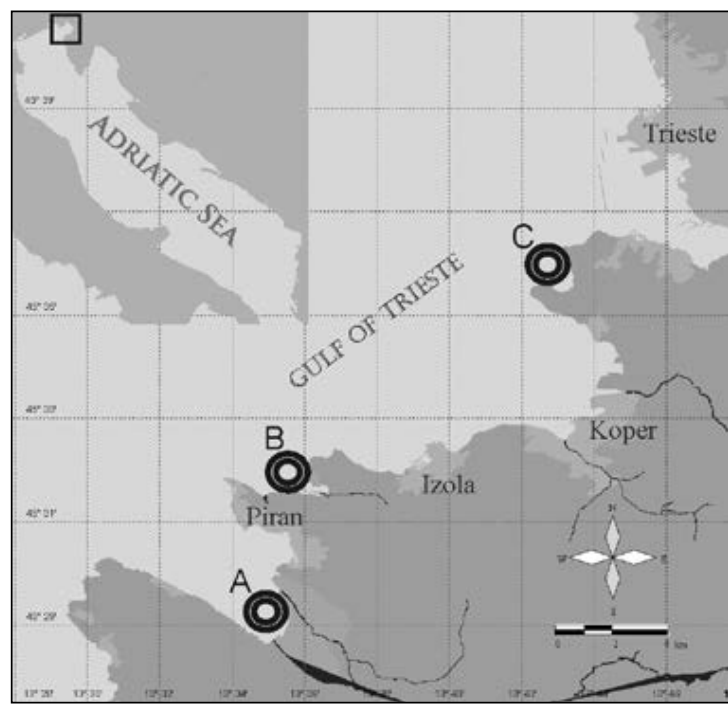

Figure 1: Study area with the three communal roost-sites: (A) Sečovlje, (B) Strunjan, (C) Debeli Rtič.

Slika 1: Območje raziskave s tremi skupinskimi prenočišči: (A) Sečovlje, (B) Strunjan, (C) Debeli Rtič.

communal roost-sites along the Slovenian coast: (1) off the Sečovlje salina (Sečovlje roost-site), (2) in the bay of Strunjan (Strunjan roost-site), and (3) at the Debeli rtič roost-site (Figure 1). Altogether 500 pellets of the Mediterranean Shag were collected from 2011 to 2013, $66 \%$ at the Sečovlje roost-site, $29 \%$ at the Strunjan roost-site and $5 \%$ at the Debeli rtič roost-site (Table 2). Most pellets were taken from buoys of shellfish farms; however, two sets of pellets were collected along the Sečovlje salina outer levee (15\%).

Pellets were carefully removed from the roosting ground on buoys or levee and frozen. Before the analysis, they were dried out in the laboratory. After a 24 hours bath in $10 \% \mathrm{NaOH}$ solution, pellets were washed to sort out skeletal remains such as otoliths and other organic remains like cephalopod beaks and decapod remains. Otoliths were used for identification of fish (Figure 2) to the lowest possible level according to scientific literature such as the key for otolith identification of the western Mediterranean sea and northern Atlantic (TUSET et al. 2008) and the available determination key AFORO found on the website (http://www. cmima.csic.es/aforo/; LOMBARTE et al. 2006). Our own extensive reference collection of otoliths also proved to be helpful in fish determination. For the assessment of the Mediterranean Shag's diet, we used the three commonest indices, dealing with the number of prey items (N\%), frequency of occurrence (FO\%) and biomass (W\%) (PINKAS et al. I97I). Additionally, we

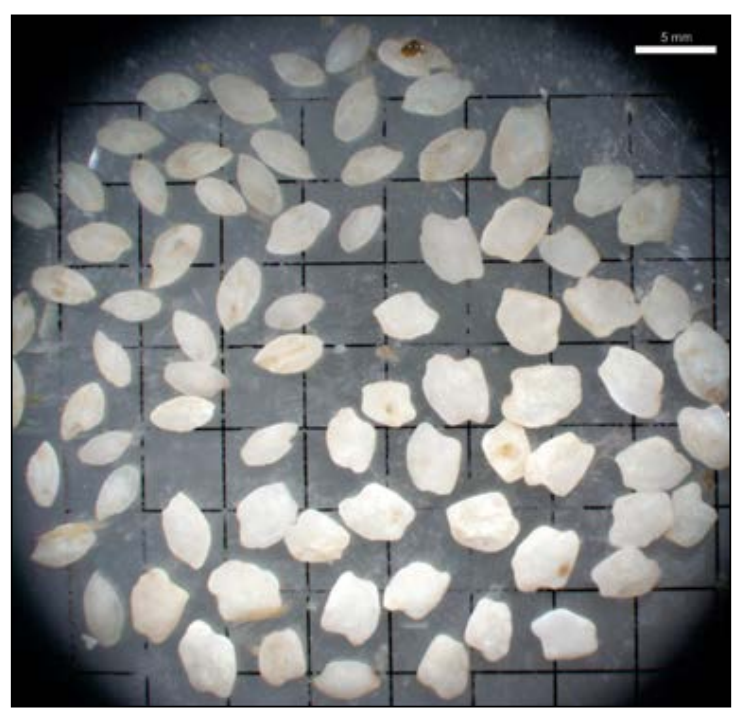

Figure 2: Sample of isolated otoliths prepared to be identified under the stereomicroscope and counted

Slika 2: Vzorec prebranih otolitov, pripravljenih za determinacijo pod mikroskopom in štetje

calculated the universal index of relative importance (IRI\%), used in fish biology (CORTES I997), which was calculated as:

$$
\begin{aligned}
& \mathrm{IRI}=(\mathrm{N} \%+\mathrm{W} \%)^{*} \mathrm{FO} \% \\
& \mathrm{IRI} \%=(\mathrm{IRI} i / \Sigma \mathrm{IRI} i j) * 100
\end{aligned}
$$

For assessing the biomass average weight of each prey species, $\left(\mathrm{W}_{\mathrm{i}}\right)$ was assessed with measurements of whole specimens of each species $i$, obtained from the study area (own data).

\section{Results}

In total, 20,430 prey items were isolated (Table 1). Four pellets were void of any otoliths or other useful remains for identification. In other pellets the number of prey items varied from 1 to 172 per pellet (Figure 3), on average 41.2 per pellet. In more than half of all pellets the number of prey items varied from 20 to 50 per pellet.

The great majority of all prey items were fish (>99\%), while decapods and cephalopods were present in negligible numbers ( 0.1 and $0.08 \%$, respectively). Otoliths of 30 fish species from 18 families were identified in the pellets. Gobies (Gobiidae) were best represented by 6 species, followed by blennies Blenniidae and sea breams Sparidae, with 3 species each (Table 1). 
Table 1: The diet of Mediterranean Shag Phalacrocorax aristotelis desmarestii in the 2011-2013 period at three roosting sites in Slovenian waters. The data for mean weight of particular prey items $\left(\mathrm{W}^{*}\right)$ was obtained by measuring samples of different fish species or from literature data. Legend: $\mathrm{N}$ - number of prey items, $\mathrm{W}$ - calculated weight, F\% - frequency of occurrence, IRI - index of the relative importance.

Tabela 1: Prehranjevalne navade sredozemskega vranjeka Phalacrocorax aristotelis desmarestii v obdobju 2011-2013 na treh počivališčih v slovenskem morju. Podatki o povprečni teži plena $\left(\mathrm{W}^{*}{ }^{*}\right)$ so bili pridobljeni z meritvami vzorcev določenih vrst rib ali povzeti po literaturnih podatkih. Legenda: $\mathrm{N}$ - število primerkov plena, W - preračunana masa, F\% - frekvenca pojavljanja, IRI - indeks relativne pomembnosti plena.

\begin{tabular}{|c|c|c|c|c|c|c|c|c|}
\hline Taxa & $\mathrm{N}$ & $\mathrm{N} \%$ & $\mathrm{~W}_{\mathrm{i}}(\mathrm{g})^{*}$ & $\mathrm{~W}(\mathrm{~g})$ & W\% & $\mathrm{F} \%$ & IRI & IRI\% \\
\hline Atherina boyeri & 478 & 2.34 & 2.5 & II 195.00 & 0.32 & $9.1 \mathrm{I}$ & 24.24 & 0.14 \\
\hline Blenniidae indet. & 27 & 0.13 & 20 & 540.00 & 0.14 & 2.43 & 0.67 & 0.00 \\
\hline Cepola macrophthalma & 624 & 3.05 & 15.4 & 9609.60 & 2.58 & 47.57 & 267.99 & 1.57 \\
\hline Chromis chromis & 19 & 0.09 & 10.5 & 199.50 & 0.05 & $0.8 \mathrm{I}$ & 0.12 & 0.00 \\
\hline Diplodus vulgaris & I & 0.00 & 25 & 25.00 & $0.0 \mathrm{I}$ & 0.2 & 0.00 & 0.00 \\
\hline Engraulis encrasicolus & 14 & 0.07 & 9.7 & 135.80 & 0.04 & $0.8 \mathrm{I}$ & 0.09 & 0.00 \\
\hline Eutrigla gurnardus & I & 0.00 & 25.7 & 25.70 & 0.01 & 0.2 & 0.00 & 0.00 \\
\hline Gadidae indet. & 18 & 0.09 & 45 & 810.00 & 0.22 & 2.02 & 0.62 & 0.00 \\
\hline Gobius cobitis & 58 & 0.28 & 35.6 & 2064.80 & 0.55 & 3.85 & 3.23 & 0.02 \\
\hline Gobius cruentatus & 75 & 0.37 & I 8.4 & 1380.00 & 0.37 & $9 . \mathrm{II}$ & 6.72 & 0.04 \\
\hline Gobius niger & 10093 & 49.40 & 22.7 & 229111.10 & 61.49 & 98.18 & $\mathrm{I} 0887.8 \mathrm{I}$ & 63.99 \\
\hline Gobiuspaganellus & I & 0.00 & 13.4 & 13.40 & 0.00 & 0.2 & 0.00 & 0.00 \\
\hline Gobius sp. & 5208 & 25.49 & 16 & 83328.00 & 22.37 & 91.09 & $4359.3 \mathrm{I}$ & 25.62 \\
\hline Merlangius merlangus & 6 & 0.03 & $55 \cdot 3$ & 331.80 & 0.09 & $\mathrm{I} . \mathrm{OI}$ & 0.12 & 0.00 \\
\hline Monochirus hispidus & 36 & 0.18 & 15.4 & 554.40 & 0.15 & 3.64 & I.I 8 & 0.01 \\
\hline Ophidion barbatus & 4 & 0.02 & 49 & 196.00 & 0.05 & $0.8 \mathrm{I}$ & 0.06 & 0.00 \\
\hline Pagellus erythrinus & $\mathrm{I} 2$ & 0.06 & $4 \mathrm{I} \cdot 3$ & 495.60 & 0.13 & $0.6 \mathrm{I}$ & 0.12 & 0.00 \\
\hline Parablennius gattorugine & 13 & 0.06 & 43.5 & 565.50 & 0.15 & 0.4 & 0.09 & 0.00 \\
\hline Parablennius rouxi & 4 & 0.02 & 15 & 60.00 & 0.02 & $0.8 \mathrm{I}$ & 0.03 & 0.00 \\
\hline Parablennius tentacularis & 5 & 0.02 & 28 & I 40.00 & 0.04 & $0.8 \mathrm{I}$ & 0.05 & 0.00 \\
\hline Phycis blennoides & 6 & 0.03 & 48.6 & 291.60 & 0.08 & 0.4 & 0.04 & 0.00 \\
\hline Pomatoschistus marmoratus & 146 & $0.7 \mathrm{I}$ & 0.25 & 36.50 & 0.01 & 12.15 & 8.80 & 0.05 \\
\hline Sardinella aurita & 3 & 0.01 & 5.8 & 17.40 & 0.00 & $0.6 \mathrm{I}$ & 0.01 & 0.00 \\
\hline Serranus hepatus & 2739 & $\mathrm{I} 3.4 \mathrm{I}$ & 9.7 & 26568.30 & $7 \cdot 13$ & 62.50 & $\mathrm{I} 287.7 \mathrm{I}$ & 7.57 \\
\hline Solea solea & I & 0.00 & 17 & 17.00 & 0.00 & 0.2 & 0.00 & 0.00 \\
\hline Spicaraflexuosa & 4 & 0.02 & 26 & 104.00 & 0.03 & 0.2 & 0.01 & 0.00 \\
\hline Spondylliosoma cantharus & I & 0.00 & 70 & 70.00 & 0.02 & 0.2 & 0.00 & 0.00 \\
\hline Symphodus cinereus & 40 & 0.20 & 24.5 & 980.00 & 0.26 & 3.85 & 1.77 & 0.01 \\
\hline Syngnathus acus & 3 & 0.01 & 13 & 39.00 & 0.01 & 0.4 & 0.01 & 0.00 \\
\hline Trachinus draco & 83 & $0.4 \mathrm{I}$ & 25.6 & 2124.80 & 0.57 & 8.7 & 8.50 & 0.05 \\
\hline Trachurus mediterraneus & 20 & 0.10 & 48.9 & 978.00 & 0.26 & $0.6 \mathrm{I}$ & 0.22 & 0.00 \\
\hline Trisopterus minutus & 95 & 0.47 & $45 \cdot 7$ & 4341.50 & 1.17 & II.94 & 19.47 & O.I I \\
\hline Zosterisessor ophiocephalus & 4 & 0.02 & 18.9 & 75.60 & 0.02 & $0.6 \mathrm{I}$ & 0.02 & 0.00 \\
\hline Pisces indet. & 550 & 2.69 & IO & 5500.00 & 1.48 & 32.66 & 136.14 & 0.80 \\
\hline Decapoda & 22 & O.II & 4.2 & 92.40 & 0.02 & 4.25 & 0.56 & 0.00 \\
\hline Cephalopoda & 16 & 0.08 & 35 & 560.00 & 0.15 & 2.02 & 0.46 & 0.00 \\
\hline Total / Skupaj & 20430 & 100.00 & & 372577.30 & 100.00 & & 17016.17 & 100.00 \\
\hline
\end{tabular}




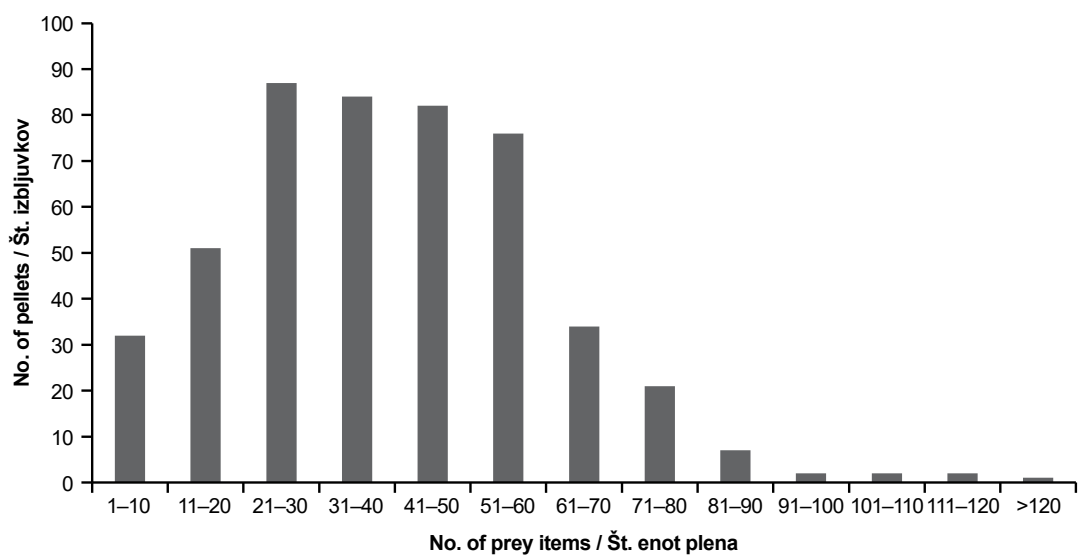

Figure 3: Number of prey items per pellet

Slika 3: Število primerkov plena na posamezni izbljuvek

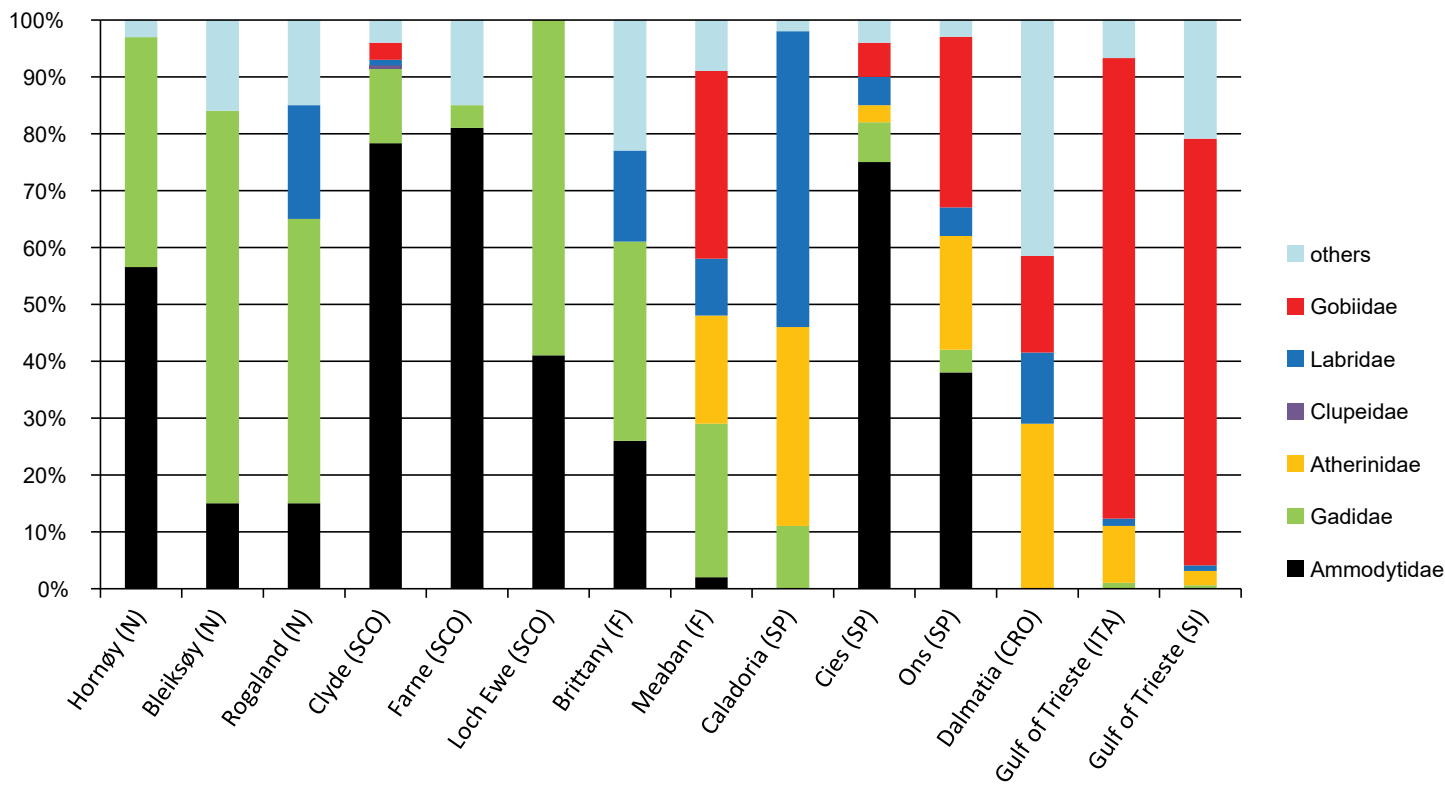

Figure 4: The diet of the European Shag Phalacocorax aristotelis in Europe in comparison with the data of this study. The diet of the subspecies $P$. a. desmarestii is denoted with asterisks. Prey items are grouped in fish families. Sites where the Shag's diet was studied: Norway: Hornøy, Bleiksøy and Rogaland (BARET et al. 1990); Scotland: Clyde, Farne and Loch Ewe (Pearson 1968, Lumsden \& Hadow 1946, Mills 1969; all cited in Velando \& Freire 1999), France: Brittany (Pasquet 1987), Meaban, Bay of Biscay (Fortin et al. 2012); Riou Archipelago (Morat et al. 2014*), Spain: Caladoria, Asturia (Alvarez 1998), Cies and Ons, Galicia (Velando \& FreIRE 1999), Croatia: Oruda, northern Adriatic (Cosolo et al. 2011*); Italy: Gulf of Trieste, northern part (Cosolo et al. 2011*) and Slovenia: southern part of the Gulf of Trieste (this work*).

Slika 4: Prehranjevalne navade vranjeka Phalacocorax aristotelis v Evropi in primerjava s podatki pričujočega dela. Dela, ki se nanašajo na prehrano sredozemske podvrste $P$. a. desmarestii, so označena z zvezdico. Plen je združen v večje prehranjevalne kategorije - ribje družine. Lokalitete, kjer so raziskovali prehrano vranjekov: Norveška: Hornøy, Bleiksøy in Rogaland (Baretr et al. 1990); Škotska: Clyde, Farne in Loch Ewe (PeARSon 1968, Lumsden \& Hadow 1946, Mills 1969; vsi citirani v delu Velando \& Freire 1999), Francija: Bretanja (PAsquet 1987), Meaban, Biskajski zaliv (Fortin et al. 2012); otočje Riou (Morat et al. 2014*), Španija: Caladoria, Asturija (Alvarez 1998), Cies in Ons, Galicija (Velando \& Freire 1999), Hrvaška: Oruda, severni Jadran (Cosolo et al. 2011*); Italy: Tržaški zaliv, severni del (Cosoto et al. 2011*) in Slovenija: južni del Tržaškega zaliva (to delo). 
Table 2: Comparison of the diet of Mediterranean Shag Phalacrocorax aristotelis desmarestii at different sites in 2011-2013. Legend: $\mathrm{P}$ - number of analyzed pellets, $\mathrm{N}$ - number of prey items, $\mathrm{N} / \mathrm{P}$ - number of prey items per pellet, $\mathrm{S}$ - number of different species or taxa, Gnig - number of Black Gobies Gobius niger in the diet, \%Gnig - percentage of Black Gobies.

Tabela 2: Primerjava prehrane sredozemskega vranjeka na različnih počivališčih v obdobju 2011-2013. Legenda: P - število analiziranih izbljuvkov, N - število primerkov plena, N/P - število primerkov plena na izbljuvek, S - število različnih vrst ali taksonov, Gnig - število črnih glavačev Gobius niger v prehrani, \%Gnig - delež črnih glavačev Gobius niger v prehrani.

\begin{tabular}{|c|c|c|c|c|c|c|c|}
\hline Roost-site / Počivališče & Date / Datum & $\mathrm{P}$ & $\mathrm{N}$ & $\mathrm{N} / \mathrm{P}$ & $S$ & Gnig & $\%$ Gnig \\
\hline Sečovlje & 2.9 .2011 & 6 & 345 & 57.50 & 8 & 145 & 42.03 \\
\hline Sečovlje & I. 7.2012 & 60 & 1601 & 26.68 & 17 & 802 & 50.09 \\
\hline Sečovlje & $5 \cdot 7 \cdot 2012$ & 17 & 659 & 38.76 & 9 & 248 & 37.63 \\
\hline Debeli rtič & 20.7 .2012 & 45 & I 245 & 27.67 & IO & 66I & 53.09 \\
\hline Strunjan & $27 \cdot 7.2012$ & 25 & 607 & 24.28 & II & $4 \mathrm{II}$ & $67.7 \mathrm{I}$ \\
\hline Sečovlje & I. 8.2012 & $2 I$ & 784 & 37.33 & 12 & 454 & 57.91 \\
\hline Sečovlje & 24.8 .2012 & 187 & 8649 & 46.25 & 30 & 4029 & 46.58 \\
\hline Sečovlje & 25.7 .2013 & 37 & 2239 & $60.5 \mathrm{I}$ & 15 & 832 & 37.16 \\
\hline Strunjan & 17.8 .2013 & 102 & 4301 & 42.17 & 17 & 2511 & 58.38 \\
\hline Total / Skupaj & & 500 & 20430 & & & & \\
\hline
\end{tabular}

The Black Goby Gobius niger was the dominant species with $49.4 \%$ in terms of abundance number and also represented the main prey species (IRI\% $=64.0)$. This number may be even greater since the second most abundant category is represented by Gobies Gobius sp. $(\mathrm{N} \%=25.5 \%$ and IRI\% $=25.6)$, which were not identified to the species level due to eroded or damaged otoliths.

The third most preyed fish was the Brown Comber Serranus hepatus with $13.4 \%$, while among other prey species only the Red Bandfish Cepola macrophthalma and Mediterranean Big-scale Sand Smelt Atherina boyeri were present with more than $1 \%$ in diet. Otoliths of the Black Goby were found in almost every pellet $(\mathrm{FO} \%=98.2 \%)$. Two additional species, Brown Comber and Red Bandfish, were present with high frequency of occurrence $(\mathrm{FO} \%=62.5$ and 47.6, respectively), followed by the Marbled Goby Pomatoschistus marmoratus $(\mathrm{FO} \%=12.2)$ and Poor Cod Trisopterus capelanus (FO\% $=12.0)$. In the case of the maximum number of prey items per pellet, all 172 preyed specimens were Big-scale Sand Smelts.

At different localities and in different samples the percentage of the Black Goby varied from $37.6 \%$ to $67.7 \%$ of all prey items (Table 2). In different samples of pellets it varied from 24.3 to 57.5 prey specimens per pellet. The diet of Mediterranean Shags from the Debeli rtič roost-site differed slightly from those in other areas by preying also a considerable amount of Big-scale Sand Smelts.

\section{Discussion}

The great majority of all preyed fish species are considered as more or less benthos dwelling species and are always closely related to the sea floor. In that regard all gobies, Red Bandfish, Greater Weever Trachinus draco and others are typical epibenthic species, whereas Brown Comber, Grey Wrasse Symphodus cinereus, Poor Cod and others are considered nectobenthic species. Only Anchovy Engraulis encrasicolus, Guilt Sardine Sardinella aurita and Horse Mackerel Trachurus mediterraneus are considered as purely nektonic species from the ecological point of view. These results fit well with the study of Cosolo et al. (201 I) in the northern Gulf of Trieste, but are in contrast to the study of MORAT et al. (2OI4) for the waters off the Riou Archipelago in France where Mediterranean Shag preyed mostly upon pelagic fish and only in low portion on benthic dwelling fish.

From an ecological perspective, the Mediterranean Shag is an important element in piscivorous guild of the northern Adriatic food web. Since it is purely specialized on preying epibenthic fish species on sedimentary bottom of the shallow Gulf of Trieste, it competes with coastal marine fish predators such as rays and skates and benthic sharks (genus Mustelus). Black Gobies seem to be the optimal prey species of the Mediterranean Shag due to their availability and easy access in the shallow environment. In fact, they are present in high numbers and easily detected by a 
visually searching predator (pers. observations). Since Black Gobies can be found more or less motionless in sandy and muddy habitats in few metres of depth, they are easily accessible and the energy expenditure for such hunting is rather low (SPONZA et al. 2010).

Although other prey species play a much less important role in the diet of the Mediterranean Shag, they are mostly found in the very same or similar benthic habitats, e.g. sandy or muddy bottoms. This applies especially to Brown Comber, Red Bandfish and Greater Weaver, Common Sole Solea solea and, to a lesser extent, to Poor Cod. Among the wrasses, which are typical coastal sea species, only the Grey Wrasse was found in pellets. In comparison with other wrasses the latter is unique in preferring unvegetated areas (LIPEJ et al. 2009), which makes it more vulnerable to predation.

The overall percentage of fish species from the more common fish families other than gobies such as wrasses (Labridae), sparids (Sparidae), and blennies (Blenniidae) is surprisingly low, never exceeding $1 \%$ of all prey items. It is rather probable that adult sparids and wrasses with deep body do not fit as an optimal prey to be preyed and swallowed by shags. On the other hand, the external anatomy of fish such as Greater Weaver, Red Bandfish and other elongate species are similar to the shape of gobiids, however, they generally bury themselves in the sand (the former) or retreat in their burrows (the latter).

Other goby species are very common in the coastal fish assemblage (e.g. LIPEJ et al. 2003), however, they were present in much lower numbers in the diet of the Mediterranean Shag. Since they are dwelling on the rocky bottom, they seem to be less vulnerable to the Shag's predation. Some gobies preferentially inhabit sea grass meadows, e.g. Grass Goby Zosterisessor ophiocephalus, which provide a shelter against avian predators.

In certain pellet samples from the protected area of Debeli rtič, one of the dominant elements in the food habits was Big-scale Sand Smelt. In the very shallow area of this site, where sandstone blocks extend far from the coast, Shags were in fact often observed to prey communally on schools of small pelagic fish, especially at the end of summer and in autumn (KoCE 2015). Big-scale Sand Smelt is not a bottom dwelling species, however, it is present in numerous schools in very shallow waters, which makes it an abundant and easily detectable prey item. Nevertheless, smelts are less relevant in terms of relative importance biomass due to the small size of the depredated specimens.

From a commercial point of view, the Mediterranean Shags prey only on a negligible number of target prey, for example Poor Cod (IRI\% $=0.11$ ).
Due to the substantial dominance of Black Gobies and other undetermined gobies we could speculate that the optimal prey size was in the size range from 7 to $14 \mathrm{~cm}$, which is the size range of this species in the Adriatic Sea (BOBAN et al. 2013). MORAT et al. (2014) pointed out the fact that fishermen are generally targeting much larger fish species.

The diet of the species Phalacrocorax aristotelis has been studied in several countries such as Norway (e.g. Barrett et al. 1990), United Kingdom (e.g. Lumsden \& Hadow 1946, Pearson i968, Mills i969), France (e.g. Fortin et al. 2012, MORAT et al. 2014), Spain (e.g. Alvarez i998, Velando \& Freire 1999) and in the Adriatic region (Cosolo et al. 20 I I). In several studies it was demonstrated that the Shag in general, preys opportunistically on various fish species. Although the diet of the European Shag is very variable in different studies and depending on the geographical area as pointed out by VELANDO \& FREIRE (1999) in the majority of studies prey of a certain fish family prevails over other prey items. In the Atlantic region prey species from families Ammodytidae and Gadidae are the main prey category, whereas in certain areas fishes from families Atherinidae, Labridae and Gobiidae represent the preferred prey. In the Adriatic sea, gobies represent an important prey category.

The results of our study fit well with the data obtained in the northern (Italian) part of the Gulf of Trieste by Cosolo et al. (201 I), which reflects the similarity of the two areas in terms of habitat characteristics and prey availability. In their study, the Black Goby was the preferred prey as well and the same was true for alternative prey species, such as the Red Bandfish, Brown Comber, Poor Cod and others. In their study, the mean number of prey items per pellet was also similar (39.26 vs 41.19 in our study). Slight differences are noticeable only in the somewhat different list preyed species and the percentage of smelts Atherinidae in their study. Although the Black Goby is a preferential prey species in the studied area, the Mediterranean Shag should be considered rather as an opportunistic predator. Since gobies are very abundant in the sandy and muddy environments of the southern part of the Gulf of Trieste (and in the northern, too, as demonstrated by Cosolo et al. $201 \mathrm{I}$ ), they are easily accessible for shags. In certain sites, smelts were present in high numbers, which prove that shags are hunting whatever is easily accessible and abundant in the hunting environment. Recently, AL IsmaIl et al. (2013) pointed out the fact that in Mallorca the Mediterranean Shags preyed on a substantial number of fish species with hard scales and venomous spines such as members of the families Scorpaenidae and Trachinidae, which 
are at the same time also well camouflaged on the sea floor. The authors believed that the Shag predation on such species may be a result of a scarcity of other more palatable prey. In our study few specimens of Greater Weaver, which is otherwise a rather common and abundant fish species in sandy and muddy bottom in the Gulf of Trieste, were found in shag's pellets and no scorpionfish at all.

\section{Acknowledgements}

The study was done within the framework of the project SIMARINE-NATURA (LIFE10NAT/SI/141), cofinanced by LIFE, the financial instrument of EU for the environment. The project was financially supported also by the Ministry of the Environment and Spatial Planning, Luka Koper d. d., Municipality of Koper, Municipality of Izola and Municipality of Piran. We thank Iztok Škornik for helping us collect pellets at the Sečovlje roost-site.

\section{Povzetek}

$\mathrm{Na}$ treh počivališčih sredozemskega vranjeka Phalacrocorax aristotelis desmarestii vzdolž slovenske obale smo nabrali 500 izbljuvkov in jih analizirali. $\mathrm{V}$ prehrani so prevladovale ribje vrste primerne velikosti, ki bivajo na morskem dnu. Dominantna vrsta $\mathrm{v}$ prehrani in glavni plen vranjeka na preučevanem območju je bil črni glavač Gobius niger (IRI\% $=64.0$ ). Izsledki raziskave potrjuje, da sredozemski vranjek pleni predvsem vrste rib, ki so za ribiče komercialno nezanimive.

\section{References}

Al-ismail S., McMinn M., Tuset V. M., Lombarte A., Alcover J. A. (2013): Summer diet of European Shags Phalacrocorax aristotelis desmarestii in southern Mallorca. - Seabird 26: 8-23.

Alvarez D. (1998): The diet of shags Phalacrocorax aristotelis L. in the Cantabrian sea (North of Spain) during the breeding season. - Seabird 20: 22-30.

Barrett R. T., Rov N., Loen J., Montevecchi W. A. (I990): Diets of shags Phalacrocorax aristotelis and cormorants $P$. carbo in Norway and possible implications for gadoid stock recruitment. - Marine Ecology Progress Series 66: 205-218.

Boban J., Isajlović I., Zorica B., ČIKeš-Keč V., VRgoč N. (2013): Biometry and distribution of the black goby Gobius niger (Linnaeus, 1758) in the Adriatic Sea. - Acta Adriatica 54 (2): 265-272.

Bordjan D., Gamser M., Kozina A., Novak J., Denac M. (2013): Roost-site characteristics of the Mediterranean Shag Phalacrocorax aristotelis desmarestii along the Slovenian coast. - Acrocephalus 34 (156/157): 5-11.
CASAUX J. R. (2003): On the accuracy of the pellet analysis method to estimate the food intake in the Antarctic shag, Phalacrocorax bransfieldensis. - Folia Zoologica 52 (2): 167-176.

CoRTEs E. (1997): A Critical review of methods of studying fish feeding based on analysis of stomach contents: application to elasmobranch fishes. - Canadian Journal of Fisheries and Aquatic Sciences 54: 726-738.

Cosolo M., Privileggi N., Cimador B., Sponza S. (201 i): Dietary changes of Mediterranean Shags Phalacrocorax aristotelis desmarestii between the breeding and postbreeding seasons in the upper Adriatic Sea. - Bird Study 58: 461-472.

Fortin M., Bost Ch. A., Maes P., Barbraud Ch. (2012): The demography and ecology of the European shag Phalacrocorax aristotelis in Mor Braz, France. - Aquatic Living Resources 26: 179-185.

Koce U. (2015): Opredelitev morskih območij IBA za sredozemskega vranjeka (Phalacrocorax aristotelis desmarestii) v Sloveniji. Poročilo za projekt SIMARINENATURA (LIFE10NAT/SI/141). - DOPPS, Ljubljana.

LIPEJ L., BONACA M.O., ŠıšKo M. (2003): Coastal fish diversity in three marine protected areas and one unprotected area in the Gulf of Trieste (Northern Adriatic). - P.S.Z.N. Marine Ecology 24: 259-273.

Lipej L., Ozebek B., Bonaca M. O., Dulčić J. (2009): Nest characteristics of three labrid species in the Gulf of Trieste (northern Adriatic Sea). - Acta Adriatica 50 (2): 139-150.

lombarte A., Chic Ò., Parisi-Baradad V., Olivella R., Piera J., García-Ladona E. (2006): A web-based environment for shape analysis of fish otoliths. AFORO Database. - Scientia Marina 70 (1): 147-152.

Lumsden W. H. R., Haddow A. J. (1946): The food of the shag (Phalacrocorax aristotelis) in the Clyde sea area. Journal of Animal Ecology 15: 35-42.

Mills D. (1969): The food of the shag in Loch Ewe, Rossshire. - Scottish Birds 5: 264-268.

Morat F., Mante A., Drunat E., Dabat J., Bonhomme P., Harmelin-Vivien M., Letourneur Y. (2014): Diet of Mediterranean European shag, Phalacrocorax aristotelis desmarestii, in a northwestern Mediterranean area: a competitor for local fisheries? - Scientific reports of PortCros National Park 28: 113-132.

PEARSON T.H. (1968): The feeding biology of sea-bird species breeding on the Farne Islands, Northumberland. Journal of Animal Ecology: 137: 53-102.

PASQUET E. (1987): Relationships between Brittany shags and seawaters resources. - Muséum National d'Histoire Naturelle, Centre de recherches sur la biologie des populations d'oiseaux, Paris.

Pinkas L. M., Oliphant S., Iverson I. L. K. (i97i): Food habits of albacore, bluefin tuna, and bonito in Californian waters. - California Fish and Game 152: 1-105.

Privileggi N. (2003): Great Cormorants Phalacrocorax carbo sinensis wintering in Friuli Venezia Giulia, Northern Adriatic: specific and quantitative diet composition. Vogelwelt 124: 237-243.

Sponza S., Cimador B., Cosolo M., Ferrero E. A. (2010): Diving costs and benefits during post-breeding movements of the Mediterranean shag in the North Adriatic Sea. - Marine Biology 157 (6): 1203-1213. 
Tuset V. M., Lombarte A., Assis C. A. (2008): Otolith atlas for the western Mediterranean, north and central eastern Atlantic. - Scientia Marina 72: 7-198.

Velando A., Freire J. (1999): Intercolony and seasonal differences in the breeding diet of European shags on the Galician coast (NW Spain). - Marine Ecology Progress Series 188: 225-236.

Prispelo / Arrived: 12.9.2016

Sprejeto / Accepted: 29.11.2016 